Original Research

\title{
Soil Microbial Functional Diversity Responses to Different Revegetation Types in Baishilazi Nature Reserve
}

\author{
Jiaojiao Deng ${ }^{1,2}$, Yongbin Zhou ${ }^{1-3}$, Xuejiao Bai ${ }^{1,3}$, Jiyao Luo ${ }^{4}$, \\ You Yin ${ }^{1,3}$, Wenxu Zhu ${ }^{1,3 *}$ \\ ${ }^{1}$ College of Forestry, Shenyang Agriculture University, Shenyang, China \\ ${ }^{2}$ College of Land and Environment, Shenyang Agriculture University, Shenyang, China \\ ${ }^{3}$ Research Station of Liaohe-River Plain Forest Ecosystem, Chinese Forest Ecosystem Research Network (CFERN), \\ Shenyang Agricultural University, Changtu, China \\ ${ }^{4}$ Liaoning Baishi Lazi National Nature Reserve Administration, Dandong, China
}

Received: 1 September 2018

Accepted: 21 October 2018

\begin{abstract}
Soil microorganisms play important roles in the dynamic regulation of organic matter in the forest ecosystem and are affected by different revegetation types. To reveal the influence of different revegetation types on soil microorganisms, we examined soil properties, soil microbial activity and diversity in Baishilazi Nature Reserve, including two planted coniferous forests (LG: Larix gmelinii, PK: Pinus koraiensis), two natural secondary broadleaf forests (JM: Juglans mandshurica, QM: Quercus mongolica), and one conifer-broadleaf forest (CB). Biolog-Eco plates were used to study soil microbial functional diversity. We found that the content of soil total $\mathrm{C}$ and total $\mathrm{N}$ existed higher under the broadleaf forests (JM, QM) than conifer-broadleaf forest $(\mathrm{CB})$ and coniferous forests (LG, PK). Carbon source utilization capacity and soil microbial activity showed significant variations among different revegetation types. Soil microbial activity of natural secondary forests was significantly higher than planted coniferous forests, and JM created the highest soil microbial activity. Heatmap and PCA plot clearly differentiated among the different samples. The broadleaf forests, conifer-broadleaf forest and coniferous forests were well separated from each other, especially along the $\mathrm{PC} 1$, and the position of conifer-broadleaf forest was intermediate. The findings of canonical correspondence analysis (CCA) suggested that soil total $\mathrm{C}$ and total $\mathrm{N}$ were the main factors affecting soil microbial functional diversity. This study investigated how shifts in soil microbial functional diversity affected by different revegetation types were operational indicators of soil quality
\end{abstract}

*e-mail: zhuwenxu.315@163.com 
in Baishilazi Nature Reserve and that the JM created the highest carbon source utilization soil microbial diversity.

Keywords: Baishilazi Nature Reserve; microbial functional diversity; carbon source utilization; soil physical-chemical characteristics; principal component analysis

\section{Introduction}

In systems between vegetation and soil, the soil microorganisms not only participate in nutrient cycling and metabolism processes, but also directly affect the biochemical cycle, play important roles in the degradation of plant litter, and indirectly affect the growth of vegetation through the improvement of non-biological factors such as soil organic matter [1]. Soil microorganisms are not only affected by ground vegetation, but also react to vegetation through its own changes, forming an interactive feedback system with vegetation [2]. Soil microbial functional diversity is an important indicator of soil microbial ecology [3].

In recent years, vegetation restoration has been used as a recovery method to reconstruct local plant and animal species and restore soil fertility. The research of soil microorganism has become a hot topic in ecology. Revegetation is the key to ecological restoration, and the restoration of an ecosystem should consider soil microbial community diversity as well as the diversity of plants [4]. The feedback effect of soil microorganisms on vegetation is especially key to the success of vegetation restoration. Therefore, research on the effect of vegetation restoration on soil microorganisms has become one of the hot issues for ecologists, and also one of the crucial means to explore the mechanism of vegetation restoration. Previous studies have investigated how comprehending the tractive forces of a relationship between the soil microbial community and plant community is comparatively interesting [5]. The classification structure of soil microbial community in different revegetation types, which may lead to differentiated physiological abilities [6], may be affected by the dominant tree species [7-8].

Soil microbes play a crucial role in the formation and decomposition of organic matter, respiration, plant nutrition and health [9-10]. Compared with the physicochemical properties of soil, soil microbial characteristics are sensitive even to small fluctuations in the environment and change very fast [11]. Microbial functional diversity is an important index to evaluate soil process and ecological function, and it is an aspect of soil microbial diversity. The diversity of the forest soil microbial community may be influenced by plant community composition and soil characteristics. Therefore, it is very important to evaluate the effect of different revegetation types on soil microbial functional diversity. The Biolog-Eco microplate technique is one of the common methods applied to evaluate the ability of microorganisms to utilize different carbon substrates. It is initially widely applied to functional diversity analysis of the soil microbial community [12-14]. It relies on the microbial inoculation extracted from the soil into microplates containing three replicate wells of 31 of the most useful carbon sources. The Biolog-Eco method is useful in comparing the functional capacity of the whole soil microbial community in contrasting environmental samples [15].

As the national nature reserves, the Baishilazi Nature Reserve is located in the mountainous region of eastern Liaoning Province, China. Baishilazi Nature Reserve was established in 1988, which belongs to the Changbai Mountain system. The original vegetation was broad-leaved Pinus koraiensis forests, which was severely damaged due to over-exploitation of the past 100 years. At present, vegetation mainly consists of natural secondary forests and coniferous plantations, which provide the unique opportunity to investigate the soil microbial community among different revegetation ecosystems under the same climatic conditions. Numerous research has investigated the changes of soil microbial biomass [16] and soil organic carbon contents [17] in different revegetation types. Yet surprisingly little is known about the detailed effect of different revegetation types, including broadleaf forest, coniferbroadleaf forest, and coniferous forest, on the soil microbial functional diversity in the Baishilazi Nature Reserve. Here we conducted a field experiment to study the functional diversity of soil microbial community metabolic activity under different revegetation types, including two planted coniferous forests (LG: Larix gmelinii, PK: Pinus koraiensis), two natural secondary broadleaf forests (JM: Juglans mandshurica, QM: Quercus mongolica), and conifer-broadleaf forest (CB). We hope this study will contribute to improving the comprehension of how vegetation alters soil microbial processes by affecting soil physicochemical characteristics, and as a result be useful for managing soil and forest.

\section{Materials and Method}

\section{Site Descriptions}

Our field research was conducted at Baishilazi Nature Reserve in the eastern mountainous areas

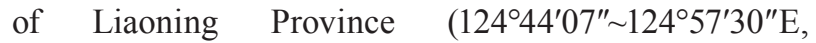
$40^{\circ} 50^{\prime} \sim 40^{\circ} 57^{\prime} 12^{\prime \prime} \mathrm{N}$ ). The total area is $7,407 \mathrm{hm}^{2}$, which belongs to the mountain range of Changbai Mountain. This area is characterized by a continental monsoon climate, with long cold winters, warm wet summers, and higher diurnal temperature variation. The annual 
mean amount of evaporation is $885 \mathrm{~mm}$. The annual average temperature is $6.4^{\circ} \mathrm{C}$, the extremely highest temperature is $34.7^{\circ} \mathrm{C}$, and the extremely lowest temperature is $-36.7^{\circ} \mathrm{C}$. Average annual precipitation is $1,158 \mathrm{~mm}$. The region has a relatively rich and unique biodiversity, possessing significant ecological status and scientific value both in China and the world.

\section{Soil Sampling}

After removal of the litter layer, a total of 15 soil samples (three plots of $20 \times 20 \mathrm{~m}$ as three independent replicates) were taken from the A horizon of each stand with the use of a soil auger $(8 \mathrm{~cm}$ in diameter, $10 \mathrm{~cm}$ deep) in July 2017. To guarantee the representativeness of soil samples in each forest, a strip sampling method was used. The soils from 15-20 points were mixed together and placed in sterile plastic bags as a replicate sample. The soil samples were taken to the laboratory immediately after being sampled by the cooling box, sieved ( $2 \mathrm{~mm}$ mesh) to removed roots and other debris, and divided into two parts. One part used for physical and chemical analyses was air-dried and the other, used for microbial activity (Biolog-Eco) measurements, was stored field-moist at $4^{\circ} \mathrm{C}$ under aerobic conditions.

\section{Biolog-Eco Measurement}

The physiological profiles of the microbial communities were analyzed using Biolog-Eco plates containing three sets of 31 carbon substrates and tetrazolium dye as the substrate utilization indicator. The substrates were classified into six substrate guilds, namely carbohydrates, amino acids, esters, alcohols, amine and acids, according to Dobranic and Zak [18]. Based on the preparation of the inoculated fluid of Classen [19], prior to the Biolog analysis, the fieldmoist soil samples were wetted at up to $60 \%$ of their maximal WHC and pre-incubated during 24 hours at $25^{\circ} \mathrm{C}$. Subsequently, the equivalent of $10 \mathrm{~g}$ of $\mathrm{DW}$ soil added with $2 \mathrm{~g}$ of glass-beads with $0.7 \mathrm{~mm}$ diameter was shaken $\left(150 \mathrm{r} \mathrm{min}{ }^{-1}, 200 \mathrm{r} \mathrm{min}^{-1}\right)$ for $30 \mathrm{~min}$ in $250 \mathrm{ml}$ of a $0.154 \mathrm{~mol} \mathrm{~L}^{-1} \mathrm{NaCl}$ solution $(\mathrm{pH}=7)$ and settled for approximately $15 \mathrm{~min}$ to decant the soil particles. The suspensions were diluted $\left(10^{-3}\right)$ in $\mathrm{NaCl}$ solution and inoculated onto Biolog-Eco plates $(150 \mu \mathrm{L}$ per well) using a multichannel pipette. All treatments had three triplicates. All plates were incubated in a temperature incubator at $25^{\circ} \mathrm{C}$, and substrate utilization was measured as the light absorbance at $590 \mathrm{~nm}$ with a multifunctional enzyme label analyzer (Infinite-M200 PRO), and subsequent readings were obtained at $24 \mathrm{~h}$ intervals for $196 \mathrm{~h}$.

\section{Measuring Average Well Color Development Values}

Average well color development (AWCD) was used to calculate the capability of microorganisms to utilize different carbon sources in microbial communities in line with the recommendations of Garland [20]. In the process of data processing, the OD value of the control well is subtracted from OD of the treatment well. The well code with negative OD well response is zero. The AWCD for replicate $j$ at time $t$ is given as follows:

$$
A W C D=\frac{1}{31} \sum_{i=1}^{31} O D i j t
$$

...where ODijt represents the corrected OD for well $i$ of replicate $\mathrm{j}$ at time $\mathrm{t}$.

\section{Calculating Metabolic Functional Diversity Indices}

The OD values at $72 \mathrm{~h}$ incubation were used to evaluate the metabolic functional diversity indices, including Shannon, Simpson, and McIntosh indices. If Pi refers to the relative ratio of optical density readings for well $\mathrm{i}$ to the combined absorbance of the whole plate, then:

Shannon index: $H=-\sum P_{i} \times \ln \left(P_{i}\right)$

Simpson index: $D=1-\sum\left(P_{i}\right)^{2}$

McIntosh index: $U=\sqrt{\left(\sum n_{i}{ }^{2}\right)}$

\section{Statistical Analyses}

All statistical analysis was performed using the SPSS software package (SPSS Inc, v 19.0, Chicago, Illinois). Differences in soil physicochemical properties and soil microbial functional diversity index among the forest stands were tested by one-way ANOVA. Variables with statistical significance in ANOVA were submitted to a multiple comparison analysis using the LSD test $(\mathrm{P}<0.05)$ [21]. In our study, measuring the absorbance values on hour 72 were used for the PCA of microbial communities' metabolic functional diversity. Canonical correspondence analysis (CCA), which was performed via Canoco 4.5, was used to evaluate the linkages between soil microbial functional diversity related to soil environmental factors in different forests [22]. In this analysis, we used the contents of total $\mathrm{C}$, total $\mathrm{N}$ and $\mathrm{C} / \mathrm{N}$ as variables representing nutrient availability for microbes and $\mathrm{pH}$ as a variable representing soil acidity. The heatmap representation of the differences of different carbon source metabolization of microbial communities among samples was built using R (R v.3.4.4) software package with gplot [23]. 
Table 1. Soil chemical and physical properties.

\begin{tabular}{|c|c|c|c|c|}
\hline Forest Stands & $\mathrm{pH}$ & $\mathrm{TC}\left(\mathrm{g} \mathrm{kg}^{-1}\right)$ & $\mathrm{TN}\left(\mathrm{mg} \mathrm{kg}^{-1}\right)$ & $\mathrm{C} / \mathrm{N}$ \\
\hline $\mathrm{JM}$ & $5.70 \pm 0.04 \mathrm{aA}$ & $100.53 \pm 7.38 \mathrm{aA}$ & $7800.00 \pm 571.67 \mathrm{aA}$ & $12.89 \pm 0.09 \mathrm{abAB}$ \\
\hline QM & $4.89 \pm 0.09 \mathrm{cC}$ & $84.62 \pm 3.32 \mathrm{bB}$ & $7375.33 \pm 1201.37 \mathrm{aA}$ & $11.65 \pm 1.56 \mathrm{bcB}$ \\
\hline CB & $4.99 \pm 0.06 \mathrm{dcC}$ & $75.49 \pm 4.26 \mathrm{cB}$ & $5466.67 \pm 331.71 \mathrm{bB}$ & $13.81 \pm 0.06 \mathrm{aA}$ \\
\hline LG & $5.40 \pm 0.05 \mathrm{bB}$ & $43.79 \pm 2.21 \mathrm{dC}$ & $3853.50 \pm 168.98 \mathrm{cC}$ & $11.36 \pm 0.11 \mathrm{cB}$ \\
\hline PK & $5.48 \pm 0.02 \mathrm{bB}$ & $41.70 \pm 0.58 \mathrm{dC}$ & $3580.50 \pm 37.86 \mathrm{dcC}$ & $11.65 \pm 0.27 \mathrm{bcB}$ \\
\hline
\end{tabular}

JM, Juglans mandshurica; QM, Quercus mongolica; MB, Mixed Broadleaf forest; BE, Betula ermanii; CB, Conifer-broadleaf forest; LG, Larix gmelinii; PK, Pinus koraiensis; PT, Pinus tabuliformis; TC, total C; TN, total N. Each treatment contained three replicates. Data were expressed as mean \pm standard error, capital letters in the same column represent a significant difference $(P<0.01)$, lower case letters mean significant differences $(P<0.05)$.

\section{Results}

\section{Chemical and Physical Properties of Soils}

The results of physical and chemical analyses were summarized in Table 1. The highest content of total $\mathrm{C}$ and total $\mathrm{N}$ in soil were measured under the $\mathrm{JM}$ with $100.53 \mathrm{~g} \mathrm{~kg}^{-1}$, and $7800.00 \mathrm{mg} \mathrm{kg}$, respectively, followed by the $\mathrm{QM}$. While total $\mathrm{C}$ and total $\mathrm{N}$ contents were lowest under the PK with $41.70 \mathrm{~g} \mathrm{~kg}^{-1}$, and $3580.50 \mathrm{mg} \mathrm{kg}^{-1}$, respectively, the decreasing order was $\mathrm{JM}>\mathrm{QM}>\mathrm{CB}>\mathrm{LG}>\mathrm{PK}$. The $\mathrm{C} / \mathrm{N}$ was highest under the $\mathrm{CB}$, with 13.81 and lowest under the LG with 11.36 , respectively. The range of $\mathrm{pH}$ values was 4.89 to 5.70 . The lowest $\mathrm{pH}$ was under $\mathrm{QM}$ with 4.89 , and the highest $\mathrm{pH}$ was under JM with 5.7 (Table 1).

\section{AWCD of Carbon Sources in Soil Microbial Communities under Five Different Revegetation Types within Incubation Time}

AWCD is an indicator of the general potential metabolic activity of the microbial community, thus it is an index of the total bioactivity for the BiologEco plates [24-25]. The change speed of the average color change value (AWCD) of the plates with different carbon sources and eventually achieving the value of the overall use of carbon source material of the microbial community is an important indicator that can reflect the soil microbial community diversity of physiological metabolism. The greater the AWCD value, the higher the density and the activity of soil microorganisms. Conversely, the microbial density and the activity are lower. As shown in Fig. 1, the variations regulation of AWCD value of five soil microorganisms increased over incubation time. The results revealed that the AWCD of all different revegetation soil exhibited an apparent lag phase in the first 24 hours. After 24 hours incubation, soil microorganisms grandly adapted to the BiologEco microplate matrix environment. The AWCD value of all five soil microorganisms increased dramatically, suggesting that the five microbial communities were able to metabolize organic substrates in Biolog-Eco microplates. We selected the period from hour 24 to hour 240 for metabolic activity analysis. During the cultivating period from hour 24 to hour 144, the increase rate of AWCD was faster, and the increase rate of AWCD was highest at hour 72, indicating that the ability of microorganisms to use carbon sources was highest. Meanwhile, the AWCD tended to be stable after 216 hours, indicating that all cultivable microorganisms could steadily use carbon sources in the stable period [26].

Among the five soil samples, the AWCD values of broadleaf forest (JM, QM) were higher than coniferbroadleaf forest (CB) and coniferous forest (LG, PK). After 216 hours, the AWCD of JM increased from 0 to 1.86 , and the AWCD of QM increased to around 1.75 , which suggested that the soil microorganisms in the JM showed the highest activity. However, the AWCD of PK increased to around 1.42 when it tended to be stable, which illustrated that the soil microbial activity of PK was the lowest. Comprehensive of the above results, there was significant difference in

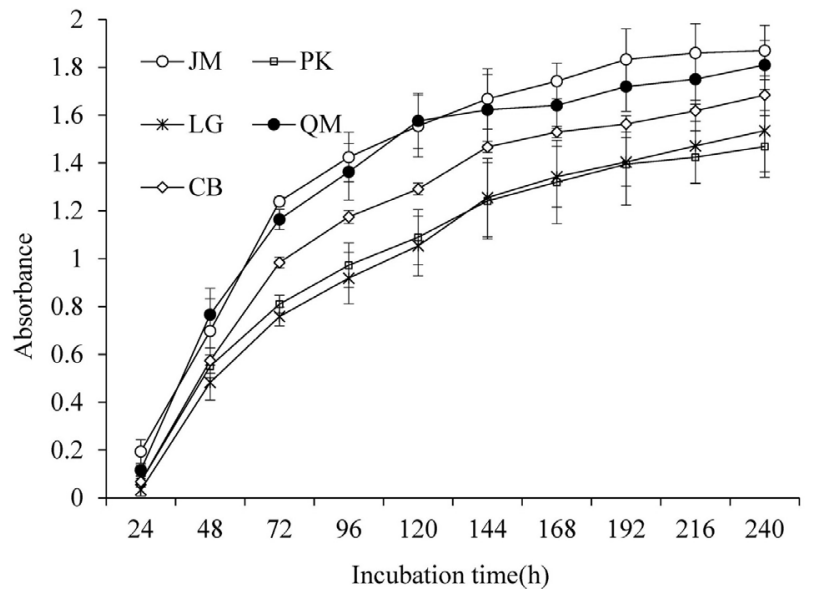

Fig. 1. The AWCD of all carbon sources in soil microbial communities in 5 different revegetation types within incubation time. JM: Juglans mandshurica; QM: Quercus mongolica; CB: Conifer-broadleaf forest; LG: Larix gmelinii; PK: Pinus koraiensis. 
Table 2. AWCD of $72 \mathrm{~h}$ for soil microbial communities and diversity indices.

\begin{tabular}{|c|c|c|c|c|}
\hline Stands & AWCD & Shannon Index & Simpson Index & Mclntosh Index \\
\hline JM & $1.24 \pm 0.02 \mathrm{aA}$ & $3.22 \pm 0.01 \mathrm{aA}$ & $0.957 \pm 0.000 \mathrm{aA}$ & $8.01 \pm 0.14 \mathrm{aA}$ \\
\hline QM & $1.16 \pm 0.04 \mathrm{bA}$ & $3.20 \pm 0.01 \mathrm{aA}$ & $0.955 \pm 0.001 \mathrm{abA}$ & $7.65 \pm 0.32 \mathrm{aA}$ \\
\hline CB & $0.98 \pm 0.02 \mathrm{cB}$ & $3.11 \pm 0.01 \mathrm{bB}$ & $0.952 \pm 0.001 \mathrm{bAB}$ & $6.72 \pm 0.17 \mathrm{bB}$ \\
\hline LG & $0.81 \pm 0.04 \mathrm{dC}$ & $3.05 \pm 0.01 \mathrm{cB}$ & $0.947 \pm 0.001 \mathrm{cB}$ & $5.78 \pm 0.23 \mathrm{cC}$ \\
\hline PK & $0.76 \pm 0.02 \mathrm{dC}$ & $3.02 \pm 0.06 \mathrm{cC}$ & $0.943 \pm 0.004 \mathrm{dC}$ & $5.61 \pm 0.10 \mathrm{cC}$ \\
\hline
\end{tabular}

Each treatment contained three replicates. Data were expressed as mean \pm standard error-capital letters in the same column represent a significant difference $(P<0.01)$, lower case letters mean significant differences $(P<0.05)$. JM: Juglans mandshurica; QM: Quercus mongolica; CB: Conifer-broadleaf forest; LG: Larix gmelinii; PK: Pinus koraiensis.

microbial utilization rates under different revegetation, the carbon source utilization capacity by soil microbial communities was in the following decreasing order of $\mathrm{JM}>\mathrm{QM}>\mathrm{CB}>\mathrm{LG}>\mathrm{PK}$.

\section{Analysis of the Variation of Functional Diversity Index of Soil Microbial Community}

In our experiment there were 31 different types of carbon source of Biolog-Eco plates, and different types of carbon sources were utilized by soil microbial communities, and their absorption values were different. Therefore, the diversity indices can reflect the diversity of the soil microbial community from different perspectives. In our study, the absorbance value of soil microorganisms at $72 \mathrm{~h}$ was adopted to analyze the Mclntosh (U), Simpson (D) and Shannon (H) indices. As shown in Table 2, the effect of different revegetation types on functional diversity of microbial communities is reflected in the diversity indices. Overall, the Shannon, Simpson, and Mclntosh indices of JM were highest, with $0.957,3.22$, and 8.01 , respectively, following the decreasing order of $\mathrm{JM}>\mathrm{QM}>\mathrm{CB}>\mathrm{LG}>\mathrm{PK}$, and there was no significant difference compared with QM $(\mathrm{P}<0.05)$. While the diversity indices of broadleaf forest (JM and QM) exhibited obviously higher than coniferous forests (LG and $\mathrm{PK}$ ) and conifer-broadleaf forest $(\mathrm{CB})(\mathrm{P}<0.01)$.

\section{Different Carbon Source Metabolization Rates of Microbial Community Response to Different Revegetation Types}

Based on the carbon source biochemical characteristics, the 31 carbon matrix of Biolog-Eco were divided into six categories: carbohydrate, amino acids, esters, alcohols, amine, and acids [27] (Table 3). Microbial metabolism fingerprint refers to the ability of microorganisms to use different carbon sources on microplates. The study and analysis of soil microorganisms with different carbon source utilization abilities is helpful to fully understand the metabolic function of microbial community characteristics. The capability utilizations of six-type carbon sources were different for different microbial communities. As shown in Fig. 2, the carbon source of $\mathrm{AWCD}>2.0$ in the metabolic fingerprint, there were 6 kinds in the $\mathrm{JM}$, including D-Cellobiose, L-Asparagine, L-Serine, D-Mannitol, N-Acetyl-D-Glucosamine and D-Malic Acid, and the AWCD of D-Mannitol was the highest

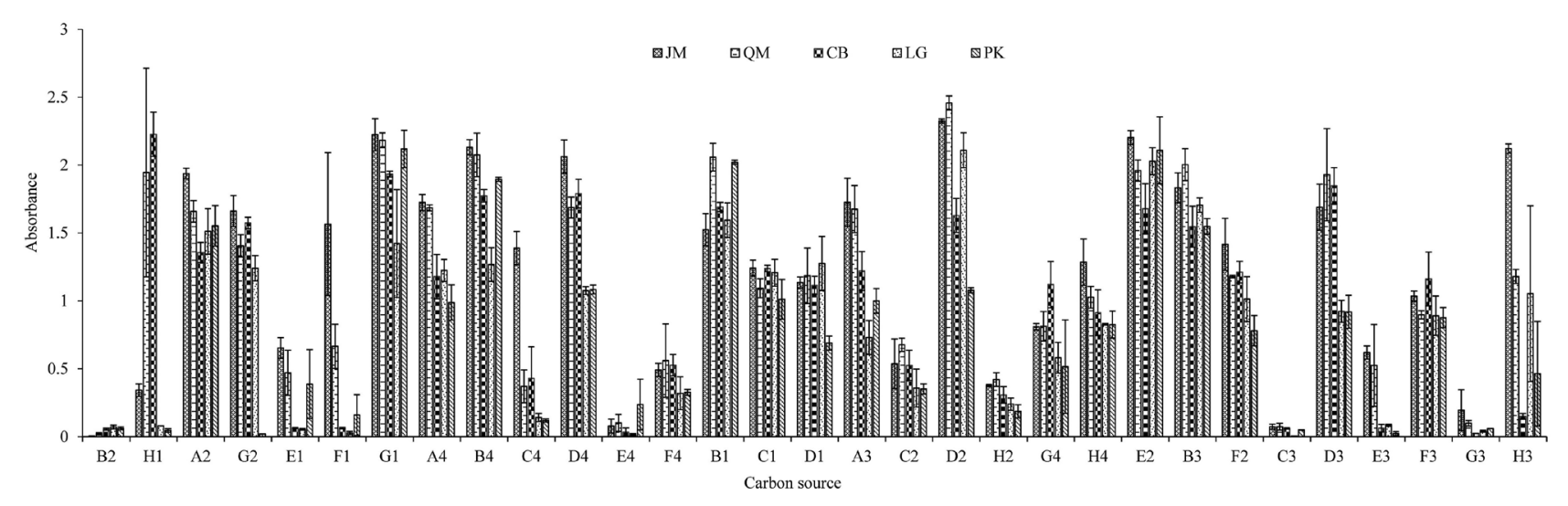

Fig. 2. Metabolic fingerprint of carbon physiological profiles of microbial community. JM: Juglans mandshurica; QM: Quercus mongolica; CB: Conifer-broadleaf forest; LG: Larix gmelinii; PK: Pinus koraiensis. B2, H1, A2, G2, E1, F1, G1: Carbohydrate; A4, B4, C4, D4, E4, F4: Amino acids; B1, C1, D1, A3: Esters; C2, D2, H2: Alcohols; G4, H4, E2: Amine; B3, F2, C3, D3, E3, F3, G3, H3: Acids. 
Table 3. Loading factors of principal components of 31 sole-carbon sources.

\begin{tabular}{|c|c|c|c|c|c|}
\hline Chemical guild & Plate number & Carbon source & Chemical formula & PCA1 & PCA2 \\
\hline \multirow{7}{*}{ Carbohydrate } & $\mathrm{B} 2$ & D-xylose & $\mathrm{C}_{5} \mathrm{H}_{10} \mathrm{O}_{5}$ & -0.922 & 0.211 \\
\hline & $\mathrm{H} 1$ & $\alpha$-D-lactose & $\mathrm{C}_{12} \mathrm{H}_{22} \mathrm{O}_{11}$ & 0.323 & 0.691 \\
\hline & $\mathrm{A} 2$ & $\beta$-methyl-D-glucoside & $\mathrm{C}_{7} \mathrm{H}_{14} \mathrm{O}_{6}$ & 0.692 & -0.536 \\
\hline & $\mathrm{G} 2$ & $\alpha$-D-glucose-1-phosphate & $\mathrm{C}_{6} \mathrm{H}_{13} \mathrm{O}_{10} \mathrm{P}$ & 0.671 & 0.639 \\
\hline & E1 & $\alpha$-cyclodextrin & $\mathrm{C}_{36} \mathrm{H}_{60} \mathrm{O}_{30} \cdot \mathrm{H}_{2} \mathrm{O}$ & 0.666 & -0.642 \\
\hline & $\mathrm{F} 1$ & Glycogen & $\left(\mathrm{C}_{6} \mathrm{H}_{10} \mathrm{O}_{5}\right)_{\mathrm{n}}$ & 0.837 & -0.361 \\
\hline & G1 & D-cellobiose & $\mathrm{C}_{12} \mathrm{H}_{22} \mathrm{O}_{11}$ & 0.55 & -0.331 \\
\hline \multirow{6}{*}{ Amino acids } & A4 & L-arginine & $\mathrm{C}_{6} \mathrm{H}_{14} \mathrm{~N}_{4} \mathrm{O}_{2}$ & 0.91 & -0.051 \\
\hline & B4 & L-asparagine & $\mathrm{C}_{27} \mathrm{H}_{18} \mathrm{C}_{13} \mathrm{~N}_{3} \mathrm{O}$ & 0.711 & -0.322 \\
\hline & $\mathrm{C} 4$ & L-phenylalanine & $\mathrm{C}_{9} \mathrm{H}_{11} \mathrm{NO}_{2}$ & 0.809 & -0.109 \\
\hline & D4 & L-serine & $\mathrm{HOCH}_{2} \mathrm{CH}\left(\mathrm{NH}_{2}\right) \mathrm{CO}_{2} \mathrm{H}$ & 0.89 & 0.275 \\
\hline & E4 & L-threonine & $\mathrm{C}_{4} \mathrm{H}_{9} \mathrm{NO}_{3}$ & -0.152 & -0.681 \\
\hline & $\mathrm{F} 4$ & Glycyl-L-glutamic acid & $\mathrm{C}_{7} \mathrm{H}_{12} \mathrm{~N}_{2} \mathrm{O}_{5}$ & 0.575 & 0.323 \\
\hline \multirow{4}{*}{ Esters } & $\mathrm{B} 1$ & Pyruvic acid methyl ester & $\mathrm{C}_{4} \mathrm{H}_{6} \mathrm{O}_{3}$ & -0.169 & -0.321 \\
\hline & $\mathrm{C} 1$ & Tween 40 & $\mathrm{C}_{22} \mathrm{H}_{2} \mathrm{O}_{6} \cdot\left(\mathrm{C}_{2} \mathrm{H}_{4} \mathrm{O}\right)_{\mathrm{n}}$ & 0.259 & 0.531 \\
\hline & D1 & Tween 80 & $\mathrm{C}_{24} \mathrm{H}_{44} \mathrm{O}_{6} \cdot\left(\mathrm{C}_{2} \mathrm{H}_{4} \mathrm{O}\right)_{\mathrm{n}}$ & 0.351 & 0.486 \\
\hline & A3 & D-galactonic acid $\gamma$-lactone & $\mathrm{C}_{6} \mathrm{H}_{10} \mathrm{O}_{6}$ & 0.913 & -0.078 \\
\hline \multirow{3}{*}{ Alcohols } & $\mathrm{C} 2$ & i-erythritol & $\mathrm{C}_{4} \mathrm{H}_{10} \mathrm{O}_{4}$ & 0.637 & 0.241 \\
\hline & D2 & D-mannitol & $\mathrm{C}_{6} \mathrm{H}_{14} \mathrm{O}_{6}$ & 0.709 & 0.187 \\
\hline & $\mathrm{H} 2$ & D,L- $\alpha$-glycerol phosphate & $\mathrm{C}_{3} \mathrm{H}_{9} \mathrm{O}_{6} \mathrm{P}$ & 0.831 & 0.241 \\
\hline \multirow{3}{*}{ Amine } & G4 & Phenylethylamine & $\mathrm{C}_{8} \mathrm{H}_{11} \mathrm{~N}: \mathrm{C}_{6} \mathrm{H}_{5} \mathrm{CH}_{2} \mathrm{CH}_{2} \mathrm{NH}_{2}$ & 0.4 & 0.606 \\
\hline & $\mathrm{H} 4$ & Putrescine & $\mathrm{C}_{4} \mathrm{H}_{12} \mathrm{~N}_{2}$ & 0.819 & -0.141 \\
\hline & E2 & N-acetyl-D-glucosamine & $\mathrm{C}_{8} \mathrm{H}_{15} \mathrm{NO}_{6}$ & 0.166 & -0.766 \\
\hline \multirow{8}{*}{ Acids } & B3 & D-galacturonic acid & $\mathrm{C}_{6} \mathrm{H}_{10} \mathrm{O}_{7}$ & 0.681 & -0.115 \\
\hline & $\mathrm{F} 2$ & D-glucosaminic acid & $\mathrm{C}_{6} \mathrm{H}_{13} \mathrm{NO}_{6}$ & 0.813 & 0.293 \\
\hline & $\mathrm{C} 3$ & 2-hydroxybenzoic acid & $\mathrm{C}_{7} \mathrm{H}_{6} \mathrm{O}_{3}$ & 0.701 & -0.058 \\
\hline & D3 & 4-hydroxybenzoic acid & $\mathrm{C}_{7} \mathrm{H}_{6} \mathrm{O}_{3}$ & 0.753 & 0.437 \\
\hline & E3 & $\gamma$-hydroxybutyric acid & $\mathrm{C}_{4} \mathrm{H}_{8} \mathrm{O}_{3}$ & 0.857 & -0.237 \\
\hline & F3 & Itaconic acid & $\mathrm{C}_{5} \mathrm{H}_{6} \mathrm{O}_{4}$ & 0.243 & 0.581 \\
\hline & G3 & $\alpha$-ketobutyric acid & $\mathrm{C}_{4} \mathrm{H}_{6} \mathrm{O}_{3}$ & 0.619 & -0.401 \\
\hline & $\mathrm{H} 3$ & D-malic acid & $\mathrm{C}_{4} \mathrm{H}_{6} \mathrm{O}_{5}$ & 0.692 & -0.378 \\
\hline
\end{tabular}

with 2.3246. There were 5 kinds in the QM, including D-Cellobiose, L-Asparagine, Pyruvic Acid Methyl Ester, D-Mannitol and D-Galacturonic Acid, and the AWCD of D-Mannitol was the highest with 2.4576. In the CB, the AECD of $\alpha$-D-Lactose was largest with 2.2266. There were 2 kinds in the LG, including D-Mannitol and N-Acetyl-D-Glucosamine, and the AWCD of D-Mannitol was the largest with 2.1098. There were 2 kinds in the PK, including Pyruvic Acid Methyl Ester and N-Acetyl-D-Glucosamine, and the AWCD of N-Acetyl-D-Glucosamine was the largest with 2.1089.
Next, heatmap analysis was used to intuitively show the differences of different carbon source metabolization rates of microbial communities appearing in all soil samples (Fig. 3), which can reflect the differences of community function of soil microorganisms in different revegetation types. The results of the heat map could be divided into three groups: corresponding coniferous forest, conifer-broad forest, and broadleaf forest. The AWCD of D-Cellobiose, L-Asparagine, D-Galacturonic Acid, D-Mannitol, L-Serine, L-Arginine, and D-Galactonic Acid $\gamma$-Lactone in the JM and QM were 


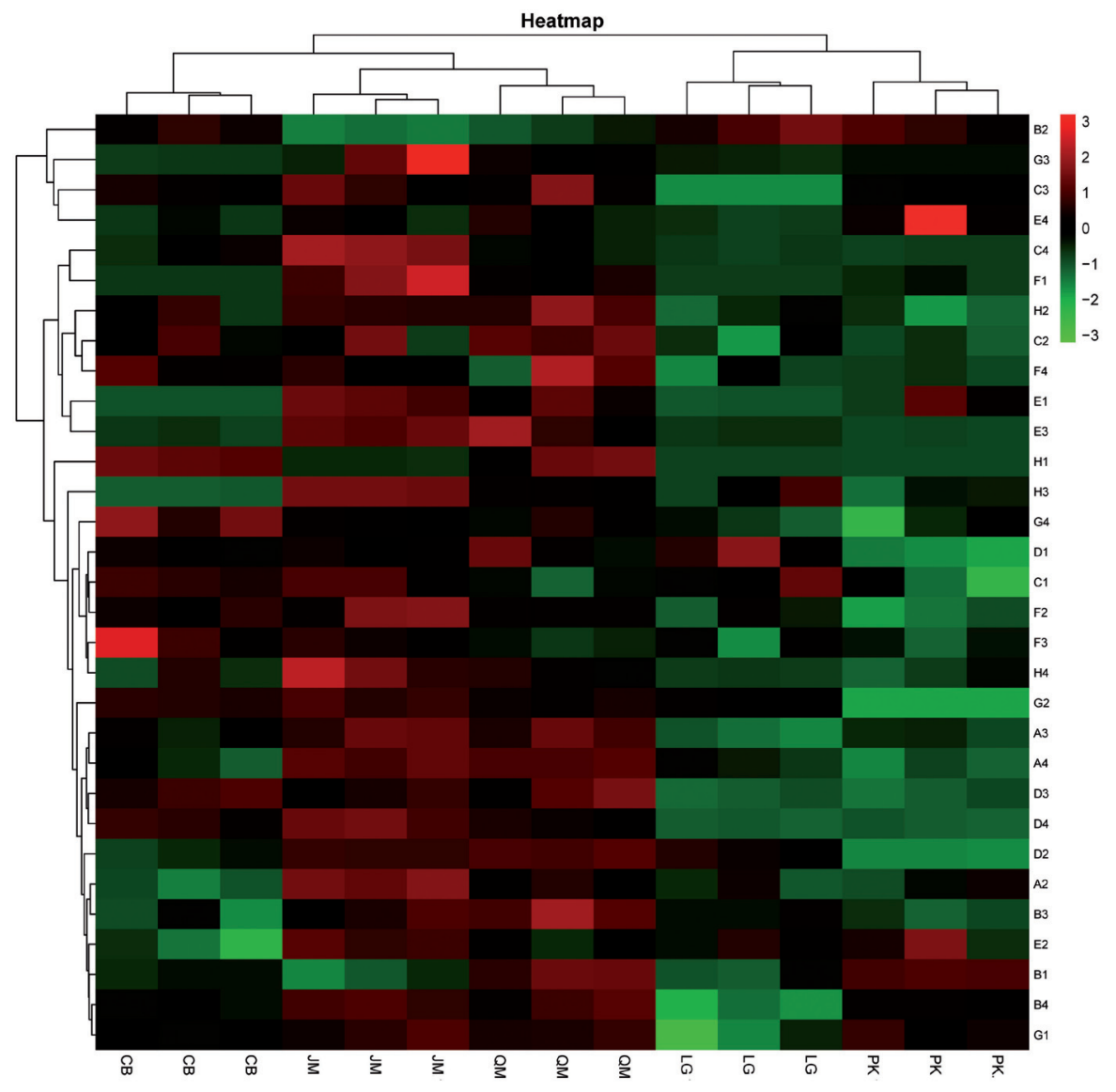

Fig. 3. Heatmap and hierarchical cluster analysis based on the AWCD of $72 \mathrm{~h}$ for soil microbial communities indifferent revegetation types. The samples are grouped based on the similarity of each other, and the clustering results are arranged horizontally according to the clustering results. In the figure, red represents the higher AWCD in the corresponding sample, and green represents the lower AWCD. JM: Juglans mandshurica; QM: Quercus mongolica; CB: Conifer-broadleaf forest; LG: Larix gmelinii; PK: Pinus koraiensis.

significantly higher than $\mathrm{CB}$, LG, and PK, indicating that the density and the activity of soil microorganisms in JM and QM were significantly higher than others.

\section{PCA of Carbon Source Metabolization}

The carbon source metabolization of microbial communities in a certain environment was evaluated using principal component analysis [28]. In Biolog-Eco, the higher the loading value of the 31 carbon sources in the main component, which means the greater the influence of the carbon source on the principal component. As shown in Table 3, there were 28 types of carbon sources that contributed to the first main subdivision (PCA1), including 6 kinds of carbohydrate, 5 kinds of amino acids, 3 kind of esters, 3 kind of alcohols, 3 kinds of Amine, and 8 kinds of acids, of which D-Galactonic Acid $\gamma$-Lactone were the most relevant carbon sources with PCA1 (0.913). Thereby, the acids made the major influence on the PCA1. Furthermore, there were 14 types of carbon sources that contributed to the second main subdivision (PCA2), including 3 kind of carbohydrate, 2 kind of amino acids, 2 kinds of esters, 3 kind of alcohols, 1 kind of amine, and 3 kinds of acid, of which $\alpha$-D-Lactose was the most relevant carbon source with PCA2 (0.691). Thereby, the carbohydrate, alcohols, and acids had a major influence on PCA2.

To explore the differences in microbial community function among different samples, the PCA was applied to extract the main components, and the variance maximized orthogonal rotation [29-30]. The multivariate vectors were transformed into two uncorrelated principal component vectors. The principal component 1 variance contribution rate was $79.38 \%$, and principal component 2 was $9.25 \%$ (Fig. 4). After dimension reduction, the differences of soil microbial metabolic characteristics in different soil samples were directly reflected by the location image of the points in the main carrier space carbon source [31], and can objectively and accurately explain the diversity of carbon source microbial utilization. PCA analysis results, based on the coordinate mapping of different treatment methods of two main components, show that the relative distance of 3 subsample points of different treatments were relatively close and separated from other groups. PCA of the carbon source metabolization of the microbial community showed that soil microbial community 


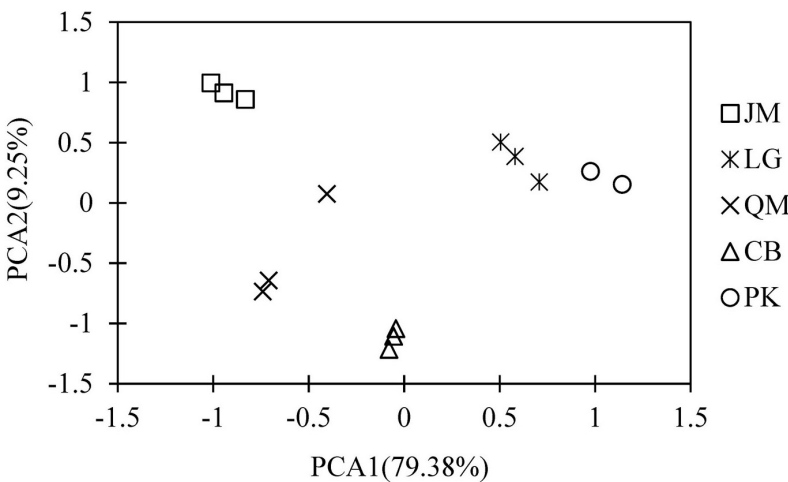

Fig. 4. Principal component analysis plot of soil carbon source Metabolization of the different microbial community. JM: Juglans mandshurica; QM: Quercus mongolica; CB: Coniferbroadleaf forest; LG: Larix gmelinii; PK: Pinus koraiensis.

function from coniferous forests (LG and PK) tended to be separated from the conifer-broadleaf forest and broadleaf forest (JM and QM), especially along PCA1 (Fig. 4). For the microbial communities under different revegetation types, the point position of JM, QM, CB, LG, and PK existed certainly differently, in particular concerning esters and carbohydrate.

\section{Relationship between Soil Microbial Functional Diversity and Physicochemical Properties}

Through typical correspondence analysis, we determined the factors that influence the soil microbial community activity and functional diversity in the forest soils. The first two CCA axes explained 99.5\% and $0.4 \%$ of the variance, respectively (Fig. 5). The first CCA axis was strongly positively related to total

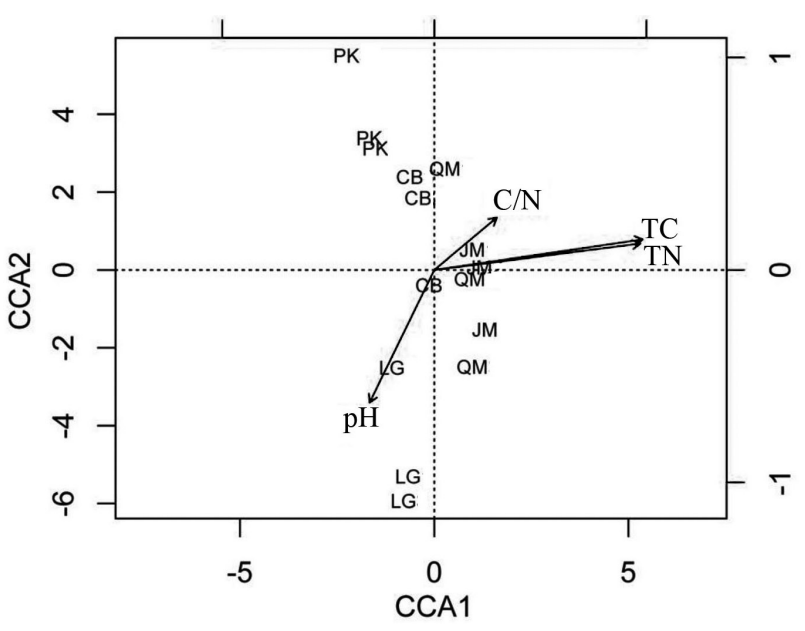

Fig. 5. The canonical correspondence analysis (CCA) ordination plots of the functional microbial community structure under different revegetation types. TC, total C; TN, total N; C.N, C/N. JM: Juglans mandshurica; QM: Quercus mongolica; CB: Conifer-broadleaf forest; LG: Larix gmelinii; PK: Pinus koraiensis.
C content $(r=0.9828)$ and TN content $(r=0.9717)$. The second CCA axis was negative correlation with soil $\mathrm{pH}$ $(r=-0.6241)$. The different revegetation types were clearly separated along the CCA axes (Fig. 5). The broadleaf forest, conifer-broadleaf forest and conifer forest were well separated from each other along the first CCA axis (Fig. 5), and the position of coniferbroadleaf forest was intermediate.

We investigated the relationships between the soil microbial functional diversity and soil measured environmental variables (Table 4). For soil properties, total C was significantly positively correlated with AWCD $(r=0.944, P<0.01)$, Shannon index $(r=0.907$, $\mathrm{P}<0.01)$, Simpson index $(\mathrm{r}=0.891, \mathrm{P}<0.01)$, and Mclntosh index $(\mathrm{r}=0.897, \mathrm{P}<0.01)$. Total $\mathrm{N}$ was significantly positively correlated with AWCD $(\mathrm{r}=0.939, \mathrm{P}<0.01)$, Shannon index $(r=0.919, P<0.01)$, Simpson index $(\mathrm{r}=0.872, \mathrm{P}<0.01)$, and Mclntosh index $(\mathrm{r}=0.895$, $\mathrm{P}<0.01)$.

\section{Discussion}

\section{Different Revegetation Types Contributing to Different Soil Physicochemical Characteristics}

Soil characteristics, climate, and vegetation are important controls on soil microbial characteristics. In our study, soil texture was similar in all the analyses, and the climate was the same. Therefore, the observed differences in soil physical-chemical characteristics and microbial functional diversity could be attributed to the influence of different quantities and qualities of organic matter input in different revegetation types. In our study, soil $\mathrm{pH}$ in the area presented acidic and ranged from 4.89 to 5.70 . And the soil $\mathrm{pH}$ under $\mathrm{QM}$ was the most acidic with 4.89 , compared to others. These differences might be related to the different chemical characteristics of the litter [32]. Compared to other broadleaf forests, the QM litter leaf quality is low, which has low nitrogen content, high $\mathrm{C} / \mathrm{N}$ ratio, higher lignin content, and higher lignin/N. Therefore, the decomposition rate of $\mathrm{QM}$ litter and the release rate of plant nutrients gradually slowed [33]. These were several reasons for the lowest $\mathrm{pH}$ value of soil under QM. Moreover, we observed that the broadleaf forest (JM, QM) ecosystem presented more contents of total $\mathrm{C}$ and total $\mathrm{N}$ compared to coniferous forests (LG and PK) and conifer-broadleaf forest (CB) (Table 2). Our results were consistent with a previous study that soil organic matter and nitrogen were higher in broadleaf forests than those under coniferous forests [34]. Similarly, several authors have already reported lower nutrient contents in coniferous stands in comparison with hardwoods stands [35-36]. The higher total $\mathrm{C}$ and total $\mathrm{N}$ in two broadleaf forests could likely be constant organic matter inputs, rhizodeposition, and the release and recycling of nutrients [37]. Evergreen coniferous 
Table 4. Correlation coefficients between soil nutrient and soil microbial functional diversity.

\begin{tabular}{|c|c|l|l|c|}
\hline & $\mathrm{pH}$ & Total C & Total N & C/N \\
\hline AWCD & -0.332 & $\mathbf{0 . 9 4 4}^{* *}$ & $\mathbf{0 . 9 3 9}^{* *}$ & 0.295 \\
\hline Shannon index & -0.327 & $\mathbf{0 . 9 0 7}^{* *}$ & $\mathbf{0 . 9 1 9}^{* *}$ & 0.246 \\
\hline Simpson index & -0.428 & $\mathbf{0 . 8 9 1}^{* *}$ & $\mathbf{0 . 8 7 2}^{* *}$ & 0.351 \\
\hline Mclntosh index & -0.274 & $\mathbf{0 . 8 9 7}^{* *}$ & $\mathbf{0 . 8 9 5}^{* *}$ & 0.262 \\
\hline
\end{tabular}

** correlation significant at 0.01 level (two-tailed); * correlation significant at 0.05 level (two-tailed)

tree species produce litter containing more lignin and leach more acids, thereby worsening decomposition compared to broadleaf litter [38]. The potential role of different forest types in varying soil $\mathrm{C} / \mathrm{N}$ ratio was also supported by previous findings [39]. In our study, the pattern of soil $\mathrm{C} / \mathrm{N}$ ratio in $\mathrm{CB}$ existed significantly higher than others, followed by the JM, which was inconsistent with previous findings that coniferous forest (pine) soil contained more carbon and had a higher $\mathrm{C} / \mathrm{N}$ than deciduous forests [40-41]. Dominating tree species affect soil characteristics through the production of litter of different quality [42]. Previous studies showed that the share of coniferous versus deciduous trees is the most influencing factor for soil [43-45].

\section{Different Revegetation Types Contributing to Different Soil Microbial Functional Diversity}

We observed a significant relationship between the different revegetation types and soil microbial functional diversity measured using Biolog-Eco plates. The soil microbial community metabolic functional diversity were actually reflected by functional diversity indices [46]. Our study showed that the soil microbial functional diversity indices were higher in broadleaf forest (JM, QM) than that of conifer-broadleaf forest and coniferous forest (LG and PK). Previous studies have shown that the Simpson index, Shannon index, and McIntosh index in natural forest were holistically higher than those in planted forest [47]. And this phenomenon was more common in other research methods [48]. In addition, the mean carbon source metabolization and soil microbial functional diversity indices were the lowest under PK soil. Our result was agreement with a previous study that showed how soil microorganisms of pine forest were characterized by a lower functional diversity H' Shannon index for Biolog-Eco than mixed and broadleaved forests in the subtropical monsoon climate in south China [49]. These findings about the functional diversity of soil microorganisms in forests were related to the dominant tree species, and the effect of different forests on soil microorganisms may be mediated by soil physicochemical characteristics [50].

In our study, the microbial community functional activity were distinctly different between the different revegetation types (Figs 3-4), which were closely linked to soil physicochemical properties (Fig. 5, Table 4). In our research, the heatmap and PCA plot showed that the microbial communities in the soil under the different revegetation types were well separated, indicating that the microbial functional diversity in the different revegetation types were distinct. A previous study found that the different plant species are colonized by different microbial communities [51-52]. For soil physicochemical properties, soil total $\mathrm{C}$ content was significantly positively correlated with AWCD, Shannon index, Simpson index and Mclntosh index. Total N was significantly positively correlated with AWCD, Shannon index, Simpson index, and Mclntosh index, which was not consistent with a previous study from Casuarina equisetifolia woodlands of different stand ages on Hainan Island [53]. Different revegetation types produce distinct quantities and qualities of plant litter input to the soil [54-55], and variations in litter quality within and between plant species will produce support for different functional microorganisms in the soil [56-57]. Therefore, these results provided supporting evidence that distinct soil properties could induce different soil microorganisms because of the formation of diverse microhabitats that support diverse collections of species, which was probably explained by decomposing the plant litter with different chemical structure.

\section{Conclusions}

In our study, we investigated how activity and functional diversity of soil microbial communities were associated with different revegetation types. The different revegetation types had significant detrimental effects on indigenous microbial community diversity and on metabolic activity in soil, as indicated by heatmap and PCA plot. Natural secondary forests (JM, $\mathrm{QM}, \mathrm{CB})$ created a higher carbon source utilization than planted coniferous forests (LG, PK) in five different revegetation types using the Biolog-ECO plate method, and the JM had the highest microbial community functional diversity. Soil total $\mathrm{C}$ and total $\mathrm{N}$ content were the major factors affecting the functional diversity of the soil microbial community in our study. Different revegetation types alter different soil microbial functional diversity through shifting soil physicalchemical characteristics. 


\section{Acknowledgements}

This research was financially supported by the subproject of the National Key Research and Develepment Program (2017YFC050410501), the Cultivation Plan for Youth Agricultural Science and Technology Innovative Talents of Liaoning Province (2015047), the Startup Foundation for Doctors of Liaoning (20170520064) and the Special Fund for Forest Scientific Research in the Public Welfare (201304216).

\section{Conflict of Interest}

The authors declare no conflict of interest.

\section{References}

1. SCHLOTER M., DILLY O., MUNCHUNCH J.C. Indicators for evaluating soil quality. Agriculture Ecosystems and Environment, 98, 255, 2003.

2. ZINN Y.L., LAL R., RESCK D.V.S. Texture and organic carbon relations described by a profile pedotransfer function for Brazilian Cerrado soils. Geoderma, 127, 168, 2005.

3. MEERSMANS J., RIDDER F.D., CANTERS F., BAETS S.D., MOLlE M.V. A multiple regression approach to assess the spatial distribution of Soil Organic Carbon (SOC) at the regional scale (Flanders, Belgium). Geoderma, 143, 1, 2008.

4. ZHENG H., OUYANG Z., WANG X., FANG Z., ZHAO T., MIAO H. Effects of forest restoration patterns on soil microbial communities. Chinese Journal of Applied Ecology, 15, 2019, 2004.

5. WAGG C., HUSBAND B.C., GREEN D.S., MASSICOTTE H.B., PETERSON R.L. Soil microbial communities from an elevational cline differ in their effect on conifer seedling growth. Plant and Soil, 340, 491, 2011.

6. SELMANTS P.C., HART S.C., BOYLE S.I., STARK J.M.. Red alder (Alnus rubra) alters community-level soil microbial function in conifer forests of the Pacific Northwest, USA. Soil Biology and Biochemistry, 37, 1860, 2005.

7. LIN Y.T., JANGID K., WHITMAN W.B., COLEMAN D.C., CHIU C.Y. Change in bacterial community structure in response to disturbance of natural hardwood and secondary coniferous forest soils in central Taiwan. Microbial Ecology, 61, 429, 2011.

8. LUCAS-BORJA M.E., CANDEL D., JINDO K., MORENO J.L., Andrés M., Bastida F. Soil microbial community structure and activity in monospecific and mixed forest stands, under Mediterranean humid conditions. Plant and Soil, 354, 359, 2012.

9. SCHULZ S., BRANKATSCHK R., DUMIG A., KOGELKNABNER I., SCHLOTER M., ZEYER J. The role of microorganisms at different stages of ecosystem development for soil formation. Biogeosciences, 10, 3983, 2013.

10. FEIGL V., UJACZKI É., VASZITA E., MOLNAR M. Influence of red mud on soil microbial communities: Application and comprehensive evaluation of the Biolog EcoPlate approach as a tool in soil microbiological studies. Science of the Total Environment, 595, 903-911, 2017.
11. GRYTA A., FRAC M., OSZUST K. The application of the Biolog EcoPlate approach in ecotoxicological evaluation of dairy sewage sludge. Applied Biochemistry and Biotechnology, 174, 1434, 2014.

12. PIERCE M.L., WARD J.E., DOBBS F.C. False positives in Biolog EcoPlates TM and MT2 MicroPlates TM caused by calcium. Journal of Microbiological Methods, 97, 20, 2014.

13. CHEN L., LIC., FENG Q., WEI Y., ZHENG H., ZHAO Y., FENG Y., LI H. Shifts in soil microbial metabolic activities and community structures along a salinity gradient of irrigation water in a typical arid region of China. Science of the Total Environment, 598, 64, 2017.

14. GE Z.W., DU H.J., GAO Y.L., QIU W.F. Analysis on Metabolic Functions of Stored Rice Microbial Communities by BIOLOG ECO Microplates. Frontiers in Microbiology, 9, 01375, 2018.

15. ROS M., GOBERNA M., PASCUAL J.A., KLAMMER S., INSAM H. 16S rDNA analysis reveals low microbial diversity in community level physiological profile assays. Journal of Microbiological Methods, 72, 221, 2008.

16. FAN A., LIU F. Seasonal Variations of Soil Microbial Biomass and Its Influence on Soil Microbial Respiration in Secondary Forest Communities in Montane Region of Eastern Liaoning Province. Journal of Northeast Forestry University, 3, 99, 2014.

17. QI J.H. Contents of soil organic carbon and its relations with physicochemical properties of secondary natural oak forests in Eastern Mountain Area of Liaoning Province. Journal of Soil and Water Conservation, 31, 135, 2017.

18. DOBRANIC J.K., ZAK J.C. A microtiter plate procedure for evaluating fungal functional diversity. Mycologia, 91, 756, 1999.

19. CLASSEN A.T., BOYLE S.I., HASKINS K.E., OVERBY S.T., HART S.C. Community-level physiological profiles of bacteria and fungi: plate type and incubation temperature influences on contrasting soils. Fems Microbiology Ecology, 44, 319, 2003.

20. GARLAND J.L. Analytical approaches to the characterization of samples of microbial communities using patterns of potential $\mathrm{C}$ source utilization. Soil Biology and Biochemistry, 28, 213, 1996.

21. BANERJEE S. Network analysis reveals functional redundancy and keystone taxa amongst bacterial and fungal communities during organic matter decomposition in an arable soil. Soil Biology and Biochemistry, 97, 188, 2016.

22. BRAAK C.J.F.T., SMILAUER P. CANOCO reference manual and CanoDraw for windows user's guide: software for canonical community ordination (version 4.5). Ithaca Ny Usa Www, 2002.

23. TEAM R.D.C. $\mathrm{R}$ : a language and environment for statistical computing. $\mathrm{R}$ Foundation for Statistical Computing, R Foundation for Statistical Computing, Vienna, Austria. Computing, 14, 12, 2009.

24. KENAROVA A., RADEVA G., TRAYKOV I., BOTEVA S. Community level physiological profiles of bacterial communities inhabiting uranium mining impacted sites. Ecotoxicology and Environmental Safety, 100, 226, 2014.

25. FRAC M., OSZUST K., LIPIEC J. Community level physiological profiles (CLPP), characterization and microbial activity of soil amended with dairy sewage sludge. Sensors, 12, 3253, 2012.

26. MIYAKE H., MAEDA Y., ISHIKAWA T., TANAKA A. Calorimetric studies of the growth of anaerobic microbes. Journal of Bioscience and Bioengineering, 122, 364, 2016. 
27. ZHANG T.Y., WU Y.H., ZHUANG L.L., WANG X.X., HU H.Y. Screening heterotrophic microalgal strains by using the Biolog method for biofuel production from organic wastewater. Algal Research, 6, 175, 2014.

28. KONG X., WANG C., JI M. Analysis of microbial metabolic characteristics in mesophilic and thermophilic biofilters using Biolog plate technique. Chemical Engineering Journal, 230, 415, 2013.

29. FELIPE-SOTELO M., TAULER R., VIVES I., GRIMALT J.O. Assessment of the environmental and physiological processes determining the accumulation of organochlorine compounds in European mountain lake fish through multivariate analysis (PCA and PLS). Science of the Total Environment, 404, 148, 2008.

30. ILLIAN J.B., PROSSER J.I., BAKER K.L., RANGELCASTRO J.I. Functional principal component data analysis: A new method for analysing microbial community fingerprints. Journal of Microbiological Methods, 79, 89, 2009.

31. KIM J.W., REHMANN L., RAY M.B. Development of microalgal bioassay based on the community level physiological profiling (CLPP). Algal Research, 25, 47, 2017.

32. AUGUSTO L., DUPOUEY J.L., RANGER J. Effects of tree species on understory vegetation and environmental conditions in temperate forests. Annals of Forest Science, 60, 823, 2003.

33. GAO J., KANG F., HAN H. Effect of Litter Quality on Leaf-Litter Decomposition in the Context of Home-Field Advantage and Non-Additive Effects in Temperate Forests in China. Polish Journal of Environmental Studies, 25, 1911, 2016.

34. JIANG Y., CHEN C., XU Z., LIU Y. Effects of single and mixed species forest ecosystems on diversity and function of soil microbial community in subtropical China. Journal of Soils and Sediments, 12, 228, 2012.

35. HUI L., YE D., WANG X., MATTEW L., Settles J., WANG Z., HAO L., ZHOU P., DONG Y.J. Soil bacterial communities of different natural forest types in Northeast China. Plant and Soil, 383, 203, 2014.

36. BELLINGRATH-KIMURA S.D., KISHIMOTO-MO A.W., OURA N., SEKIKAWA S., YONEMURA S., SUDO S., HAYAKAWA A., MINAMIKAWA K., TAKATA Y., HARA H. Differences in the spatial variability among $\mathrm{CO}_{2}, \mathrm{CH}_{4}$, and $\mathrm{N}_{2} \mathrm{O}$ gas fluxes from an urban forest soil in Japan. Ambio, 44, 55, 2015.

37. WANG G., CAO F. Integrated evaluation of soil fertility in Ginkgo (Ginkgobiloba L.) agroforestry systems in Jiangsu, China. Agroforestry Systems, 83, 89, 2011.

38. ADAMCZYK B., KITUNEN V., SMOLANDER A. Protein precipitation by tannins in soil organic horizon and vegetation in relation to tree species. Biology and Fertility of Soils, 45, 55, 2008.

39. MCGRODDY M.E., DAUFRESNE T., HEDIN L.O. Scaling of C:N:P Stoichiometry in Forests Worldwide: Implications of Terrestrial Redfield-Type Ratios. Ecology, 85, 2390, 2004.

40. YOSHIMURA C., GESSNER M., TOCKNER K., FURUMAI H. Chemical properties, microbial respiration, and decomposition of coarse and fine particulate organic matter. Journal of the North American Benthological Society, 27, 664, 2008.

41. BARBIER S., GOSSELIN F., BALANDIER P. Influence of tree species on understory vegetation diversity and mechanisms involved-A critical review for temperate and boreal forests. Forest Ecology and Management, 254, 1, 2008.

42. KIIKKILA O., KITUNEN V., SMOLANDER A. Dissolved soil organic matter from surface organic horizons under birch and conifers: degradation in relation to chemical characteristics. Soil Biology and Biochemistry, 38, 737, 2006.

43. CHODAK M., NIKLINSKA M. Effect of texture and tree species on microbial properties of mine soils. Applied Soil Ecology, 46, 268, 2010.

44. HANSSON K., OLSSON B.A., OLSSON M., JOHANSSON U., KLEJA D.B. Differences in soil properties in adjacent stands of Scots pine, Norway spruce and silver birch in SW Sweden. Forest. Forest Ecology and Management, 262, 522, 2011.

45. PRESCOTT C.E., GRAYSTON S.J. Tree species influence on microbial communities in litter and soil: current knowledge and research needs. Forest Ecology and Management, 309, 19, 2013.

46. ZHANG H., LI G., SONG X., YANG D., LI Y., QIAO J., ZHANG J., ZHAOS. Changes in soil microbial functional diversity under different vegetation restoration patterns for Hulunbeier Sandy Land. Acta Ecologica Sinica, 33, 38, 2013.

47. WU Z.Y., LIN W.X., CHEN Z.F., FANG C.X., ZHANG Z.X., WU L.K., ZHOU M.M., SHEN L.H. Characteristics of soil microbial community under different vegetation types in Wuyishan National Nature Reserve, East China. Chinese Journal of Applied Ecology, 24, 2301, 2013.

48. MASAYUKI U., KANEHIRO K., TERIC B. Tree species-mediated spatial patchiness of the composition of microbial community and physicochemical properties in the topsoils of a tropical montane forest. Soil Biology and Biochemistry, 42, 1588, 2010.

49. FANG H., CHENG S., WANG Y., YU G., XU M., DANG X., LI L., WANG L. Changes in soil heterotrophic respiration, carbon availability, and microbial function in seven forests along a climate gradient. Ecological Research, 29, 1077, 2014.

50. MENYAILO O.V., HUNGATE B.A., ZECH W. The effect of single tree species on soil microbial activities related to $\mathrm{C}$ and $\mathrm{N}$ cycling in the Siberian artificial afforestation experiment. Plant andSoil, 242, 183, 2002.

51. BOWMAN W.D., STELTZER H., ROSENSTIEL T.N., CLEVEL C.C., MEIER C.L. Litter effects of two cooccurring alpine species on plant growth, microbial activity and immobilization of nitrogen. Oikos, 104, 336, 2004.

52. SHI S., RICHARDSON A.E., O'CALLAGHAN M., DEANGELIS K.M., JONES E.E., STEWART A., FIRESTONE M.K., CONDRON L.M. Effects of selected root exudate components on soil bacterial communities. Fems Microbiology Ecology, 77, 600, 2011.

53. LI X.R., WEI J.Y., CHEN Y, CAO T.T, FENG L., GU M.Z., LI L. Functional diversity of soil microorganisms in Casuarina equisetifolia woodlands of different stand ages in Hainan Island. Chinese Journal of Plant Ecology, 38, 608, 2014.

54. USHIO M., KITAYAMA K., BALSER T.C. Tree species effects on soil enzyme activities through effects on soil physicochemical and microbial properties in a tropical montane forest on Mt. Kinabalu, Borneo. Pedobiologia, 53, 227, 2010.

55. PREVOST-BOURE N.C., MARON P.A., RANJARD L., NOWAK V., DUFRENE E., DAMESIN C., SOUDANI K., 
LATA J.C. Seasonal dynamics of the bacterial community in forest soils under different quantities of leaf litter. Applied Soil Ecology, 47, 14, 2011.

56. MYERS R.T., ZAK D.R., WHITE D.C., PEACOCK A. Landscape-level patterns of microbial community composition and substrate use in upland forest ecosystems. Soil Science Society of America Journal, 65, 359, 2001.

57. SARIYILDIZ T., ANDERSON J.M. Interactions between litter quality, decomposition and soil fertility: a laboratory study. Soil Biology and Biochemistry, 35, 391, 2003. 